\title{
Golden Age of Fluorenylidene Phosphaalkenes-Synthesis, Structures, and Optical Properties of Heteroaromatic Derivatives and Their Gold Complexes
}

Joshua P. Green, Daniel Morales Salazar, Arvind Kumar Gupta, and Andreas Orthaber*

Cite This: J. Org. Chem. 2020, 85, 14619-14626

Read Online

ACCESS | Lلll Metrics \& More | 国 Article Recommendations ｜（s Supporting Information

ABSTRACT: The substitution of 2,7-dibromo-9-fluorenyl phosphaalkenes with heteroaromatic substituents (bithiophene, benzothiophene, pyridine) offers access to interesting push-pull dye molecules. Steric shielding due to the bulky P-substituent gives marked different reactivities at the 2- and 7-positions, allowing the synthesis of mixed/asymmetric derivatives. Further functionalization via gold(I) coordination was demonstrated and increased the acceptor character, concomitant with a red-shifted absorption.

\section{INTRODUCTION}

The construction of extended $\pi$-conjugated frameworks can be rationally based on the combination of different conjugated aromatic building blocks. ${ }^{1,2}$ The combination of suitable donor and acceptor units often leads to interesting optical and electronic properties. ${ }^{3,4}$ For example, 9,9-dialkylated fluorene derivatives (Figure 1, I) have been used extensively as efficient
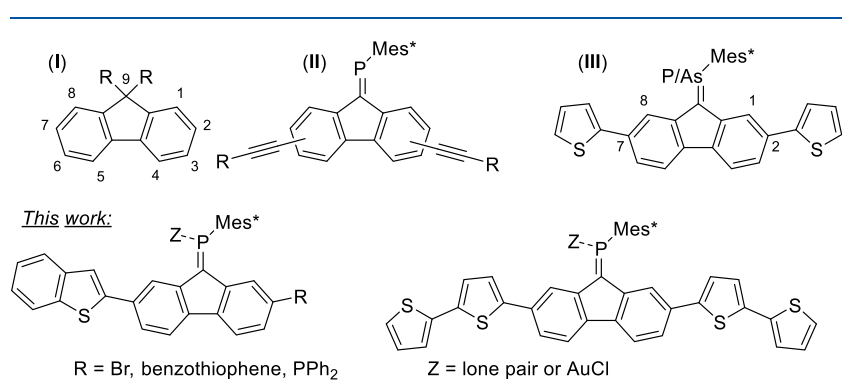

Figure 1. Molecular fluorene derivatives, including the numbering scheme used herein (top, I and III) as well as various phospha/arsaalkene derivatives.

$\pi$-spacers in the construction of photoluminescent materials, dyes for dye-sensitized solar cells, and other optoelectronic applications. $^{5-11}$ The dialkylation significantly enhances solubility and has an influence on molecular packing, e.g., $\pi$ stacking; however, it does not significantly alter the optical and electronic properties compared to the parent $2 \mathrm{H}$-fluorene. ${ }^{12}$ Similarly, dibenzoheteroles of group 14 to 16 have found widespread use as optoelectronic materials. ${ }^{13-18}$ Fluorene cores can also be functionalized with thiophene or benzothiophene moieties to provide diverse optoelectronic

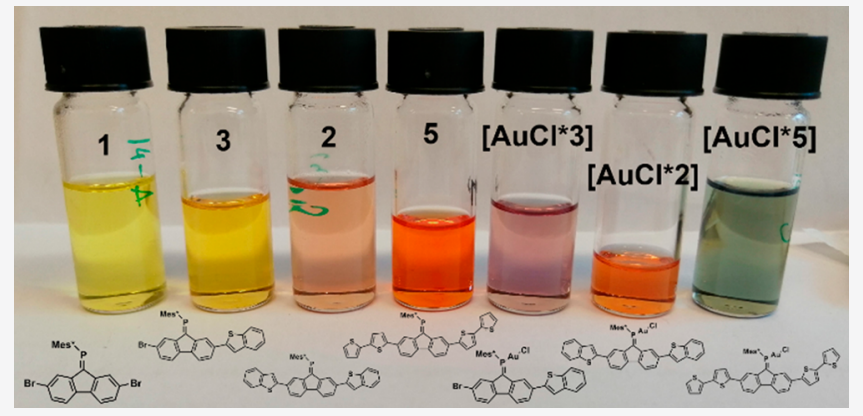

properties such as solvatochromism, tunable emission, etc. ${ }^{19-23}$

The incorporation of main group elements into $\pi$ conjugated materials has been identified as a promising path to new functional materials with outstanding optoelectronic properties. ${ }^{24-27}$ In particular, phosphorus has led to a number of interesting optoelectronic materials that exploit its variable bonding situations and coordination modes. ${ }^{28}$ Over the past years, our group has been interested in utilizing the fluorene core as a strong acceptor unit by introducing supermesitylphosphinidene or -arsinidene fragments (Mes*-P: or Mes*As:, where Mes* ${ }^{*}$ 2,4,6-tri-tert-butyl phenyl) at the bridgehead position (Figure 1, II and III). ${ }^{29}$ This sterically demanding substituent greatly affects solubility and the solidstate packing of these materials, and the possible metal coordination is expected to have similar effects. Notably, the steric demand of the Mes* substituent also has a remarkable effect on the reactivity and electronic situation of the two sides of the molecule, as reflected in the low and high NMR frequencies of protons in the 1- and 8-positions of such compounds, respectively. ${ }^{30,31}$

Herein, we describe the synthesis of novel thiophene and benzothiophene derivatives using Stille coupling of the parent 2,7-dibromo-fluorenylidene phosphaalkene and suitable stann-

Special Issue: The New Golden Age of Organophosphorus Chemistry

Received: June 5, 2020

Published: August 24, 2020

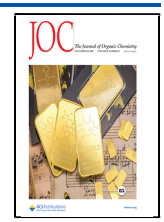


yl derivatives. The different environments at the 2- and 7positions caused by the steric demand of the Mes* substituent allow for selective monofunctionalization at the less hindered position, while difunctionalization requires harsher reaction conditions. Solid-state structures of these derivatives are reported, together with optical characterizations and theoretical studies of these products.

\section{RESULTS AND DISCUSSION}

The common precursor for the target molecules was the 2,7dibromo-fluorenyl phosphaalkene (1). Initially we attempted the derivatization of this building block using Suzuki-type coupling protocols; however, the tested conditions did not result in $\mathrm{C}-\mathrm{C}$ coupling and/or were incompatible with the phosphaalkene moiety, mostly leading to degradation products of the $\mathrm{P}=\mathrm{C}$ bond, for example, by the formation of the corresponding (partially) brominated fluorenyl ketone and the Mes*-phosphinic acid. ${ }^{32}$ Thus, milder coupling conditions were required. Stille coupling protocols often perform well at moderately elevated temperatures and do not require additional components such as inorganic bases (Scheme 1). First,

\section{Scheme 1. Synthesis of Fluorenyl Phosphaalkene} Derivatives Using Stille Coupling Reactions ${ }^{a}$

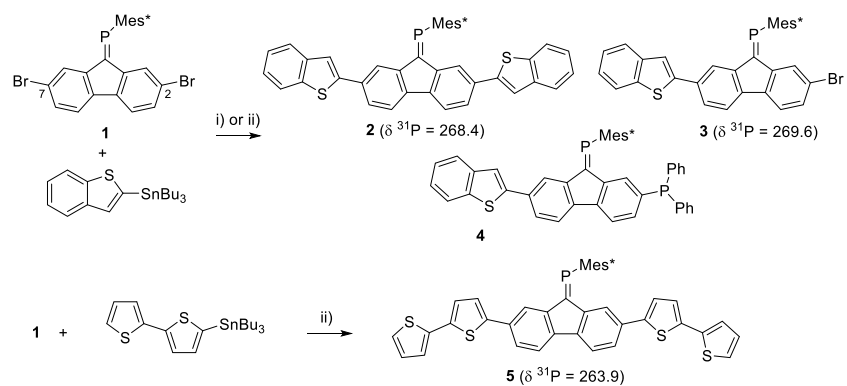

${ }^{a}(\mathrm{i}) \mathrm{THF},\left[\mathrm{Pd}\left(\mathrm{PPh}_{3}\right)_{4}\right], \mu \mathrm{w} 60 \mathrm{~min} 120{ }^{\circ} \mathrm{C}$. (ii) THF, $\left[\mathrm{Pd}\left(\mathrm{PPh}_{3}\right)_{4}\right]$, $\mu \mathrm{w} 45 \mathrm{~min} 120^{\circ} \mathrm{C}$.

we attempted the synthesis of the 2,7-di(2-benzo[b]thiophene) derivative 2 by conventional and microwave heating using $\left[\mathrm{Pd}\left(\mathrm{PPh}_{3}\right)_{4}\right]$ as a catalyst. Despite an excess of the stannyl reagent, analysis of the ${ }^{31} \mathrm{P}$-spectra of the crude reaction mixture indicated formation of a variety of different species containing phosphorus centers in both the phosphaalkene and phosphine region. Chromatographic workup afforded the targeted disubstituted derivative in $5 \%$ isolated yield. The ${ }^{31} \mathrm{P}$-resonance at $268.4 \mathrm{ppm}$ is in the expected range for this compound and is indicative of a normally polarized fluorenyl phosphaalkene. Despite the isolation of $\mathbf{2}$ in low yield, all reaction conditions tested gave the monosubstituted product 3 as the major product. The presence of a single isomer of 3 was confirmed by NMR spectroscopy, with a single ${ }^{31} \mathrm{P}$ resonance at $269.6 \mathrm{ppm}$ and one set of proton/carbon signals being detected. This behavior can be rationalized by the different environments at the fluorenyl core introduced by the phosphaalkene moiety and the steric demand of the Mes* substituent, which shields the $\mathrm{C} 2-\mathrm{Br}$ group significantly and reduces its reactivity. The spatial proximity of the Mes* group is also reflected in the low-frequency resonance of proton $\mathrm{H} 1$ due to the ring current effect, with the observed shift being $5.43 \mathrm{ppm}$.

Further attempts to increase formation of 2 using harsher reaction conditions such as increased reaction time and temperature led to the formation of another derivative, which upon separation via chromatography could be identified by selective crystallization from several fractions as the 2diphenylphosphine-7-benzothiophene derivative 4. Due to the small quantities of this side product, only single crystal analysis could be performed. The $\mathrm{PPh}_{2}$ fragment could originate from $\mathrm{Ph}_{2} \mathrm{P}-\mathrm{C}_{6} \mathrm{H}_{5}$ cleavage of a triphenylphosphine ligand in the catalytically active palladium $\left[\mathrm{Pd}\left(\mathrm{PPh}_{3}\right)_{n}\right]$ species, which could interfere with the productive transmetalation step. ${ }^{33,34}$ This is particularly plausible due to the large $\mathrm{SnBu}_{3}$ stannyl groups at the sterically shielded 2-position of the thiophene/benzothiophene reagents. We also attempted coupling of bithiophene to 1, encountering similar difficulties. Nonetheless, we were able to obtain the targeted disubstituted product 5 in ca. $15 \%$ yield using a microwave Stille coupling protocol (see details in the Experimental Section). Similar behavior was also observed in the attempted coupling of thiophene (using $\mathrm{C}_{4} \mathrm{SH}_{4}-\mathrm{SnBu}_{3}$ ), which predominantly afforded the monosubstituted derivative 6 (for details see the SI). Further attempts to couple other heteroaromatic units proved similarly difficult (Scheme 2).

Scheme 2. Coupling Reactions of 1 with 2-Stannyl Pyridine ${ }^{a}$

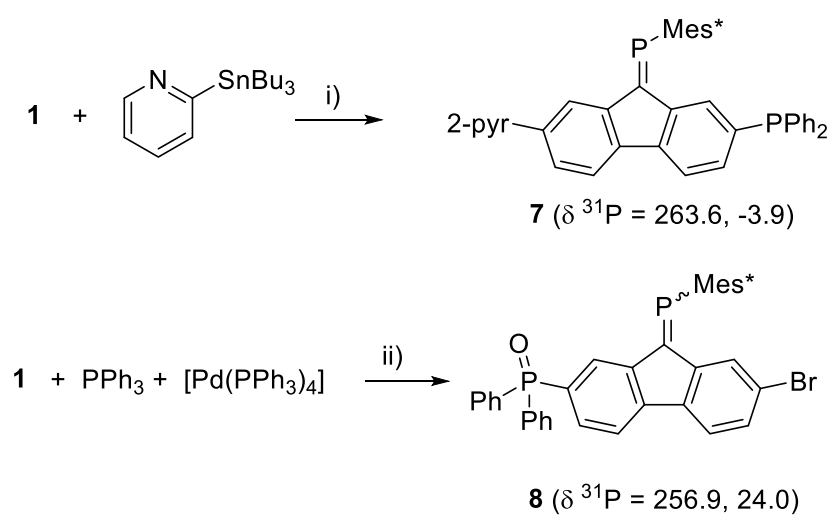

${ }^{a}(\mathrm{i}) \mathrm{THF},\left[\mathrm{Pd}\left(\mathrm{PPh}_{3}\right)_{4}\right], \mu \mathrm{w} 45 \mathrm{~min}, 140{ }^{\circ} \mathrm{C}$ and in the absence of a stannyl reagent. (ii) THF, $\mu \mathrm{w} 90 \mathrm{~min}, 165^{\circ} \mathrm{C}$.

The coupling of 1 with 2-tributylstannylpyridine using similar conditions as before gave the mixed pyridyl/diphenylphosphine derivative 7 as the only isolated product in $10 \%$ yield. In order to investigate this reactivity, we reacted $\mathbf{1}$ with $\left[\mathrm{Pd}\left(\mathrm{PPh}_{3}\right)_{4}\right]$ and excess triphenylphosphine under microwave heating in THF. From the crude reaction mixture, we identified residual starting material $1\left(\delta^{31} \mathrm{P}=272.7 \mathrm{ppm}\right)$, a mixture of the two monobromo derivatives (7-bromofluorenylidene phosphaalkene and 2-bromo-fluorenylidene phosphaalkene, $\delta{ }^{31} \mathrm{P}=268.9$ and $264.0 \mathrm{ppm}$, respectively; see SI Figure 19), ${ }^{30}$ and a phosphaalkene species in which the ${ }^{31} \mathrm{P}$ peak had shifted to lower frequencies $\left(\delta^{31} \mathrm{P}=255.2 \mathrm{ppm}\right)$. Chromatographic workup allowed us to identify this compound as the 7-diphenylphosphine oxide-2-bromo-fluorenyl phosphaalkene 8. Preliminary work using $\mathrm{Ph}_{2} \mathrm{P}(\mathrm{TMS})$ as diphenylphoshine source gave promising results, which will be subject of future work. ${ }^{35} \mathrm{We}$ assume that oxidation of the phosphine was either a result of traces of water/hydroxide under these harsh reaction conditions ${ }^{36}$ or took place during workup.

Having sufficient quantities of $\mathbf{2}, \mathbf{3}$, and $\mathbf{5}$ on hand, we also tested their behavior as ligands toward $\mathrm{Au}(\mathrm{I})$. A dichloromethane solution of the respective phosphaalkene was reacted 
at room temperature with a solution of $[\mathrm{AuCl}(t h t)](t h t=$ tetrahydrothiophene) to give the corresponding gold chloride complex quantitatively upon removal of all volatiles (Scheme 3). Immediate reaction can also be judged by the intense color

Scheme 3. Gold(I) Coordination of Derivatives 2, 3, and $5^{a}$

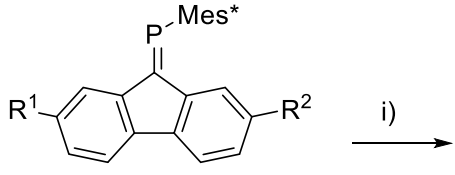

2: $R^{1}=R^{2}=2$-benzothiophene

3: $\mathrm{R}^{1}=2$-benzothiophene, $\mathrm{R}^{2}=\mathrm{Br}$

5: $R^{1}=R^{2}=2$-bithiophene

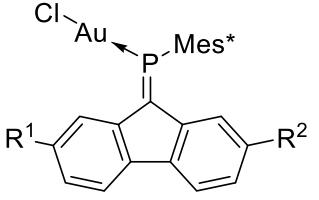

$\left[\mathrm{AuCl}{ }^{*} n\right]$
${ }^{a}$ (i) DCM, r.t., 2 h.

change, i.e., red-shifted absorption, upon addition of the gold(I) solution. Complex $\left[\mathrm{AuCl}^{*} 3\right]$ showed a ${ }^{31} \mathrm{P} \mathrm{NMR}$ resonance of $182.4 \mathrm{ppm}$, which corresponds to a coordination shift $\left(\Delta \delta^{31} \mathrm{P}\right)$ of $-87.2 \mathrm{ppm}$ and is indicative of a strong $\mathrm{Au}-\mathrm{P}$ interaction. ${ }^{37-39}$ Notably, the proton in proximity to the $\mathrm{Au}$ center was shifted to higher frequencies (9.91 ppm compared to $8.58 \mathrm{ppm}$ ), while the proton at position-1, which was directly positioned in the ring current of the Mes* substituent, was shifted further to lower frequencies ( $5.27 \mathrm{ppm}$ compared to $5.43 \mathrm{ppm}$ ). The corresponding disubstituted derivative 2 showed similar behavior upon complexation to gold(I). A coordination shift of $\Delta \delta{ }^{31} \mathrm{P}=-87.0 \mathrm{ppm}$ and a high frequency proton shift to $9.93 \mathrm{ppm}$ (compared to $8.63 \mathrm{ppm}$ in 2) indicate similar $\mathrm{AuCl}$ coordination. The gold(I) complex of 5 was characterized by a coordination shift of $\Delta \delta^{31} \mathrm{P}=-84.3$ ppm, which was the smallest shift observed among this series. The diagnostic shielded aromatic proton was only slightly more shielded (from 6.31 to $6.23 \mathrm{ppm}$ ), while the highfrequency proton was more significantly affected (from 8.47 to $9.74 \mathrm{ppm}$ ).

Crystallographic and Spectroscopic Characterization. Compound $\mathbf{2}$ crystallized in the monoclinic space group $P 2_{1} / c$ as dark red needles. The molecule showed disorder in the unhindered benzothiophene, with S2A/S2B having 0.58:0.42 occupancy (Figure 2). On the other hand, the sterically shielded benzothiophene containing S1 showed no signs of disorder. The former was almost coplanar with the fluorene moiety (twist angle $1.9(2)^{\circ}$ ), while the latter was significantly distorted from coplanarity $\left(24.1(1)^{\circ}\right)$. The $\mathrm{P}=\mathrm{C}$ bond was 1.691(3) $\AA$, and the $\mathrm{C}-\mathrm{P}=\mathrm{C}$ angle of $106.7(1)^{\circ}$ was in the expected range for these compounds $(147 \mathrm{CP}=\mathrm{C}$ fragments mean $\mathrm{P}=\mathrm{C}$ distance and $\mathrm{C}-\mathrm{P}=\mathrm{C}$ angle $1.689 \AA$ and $\left.103.7^{\circ}\right) .{ }^{40-42}$ The difference in steric demand is also reflected in the $\mathrm{P}-\mathrm{C} 1-\mathrm{C} n$ angles, which were $119.0(2)^{\circ}$ and $135.6(2)^{\circ}$ toward $\mathrm{C} 2$ and $\mathrm{C} 5$, respectively. The extended $\pi$-conjugated system led to interesting stacking in the solid state, with slipped $\pi-\pi$ stacking roughly positioning a benzothiophene unit above the fluorenyl phosphaalkene $\pi$-system. One short centroid-centroid distance of $3.77 \AA$ and several slightly longer ones $(>4.2 \AA)$ can be calculated.

Compound 3 crystallized as dark orange needles in the orthorhombic space group Pcnn with two independent molecules in the asymmetric unit, one of which showed benzothiophene disorder $(0.86: 0.14)$, as well as the para-tertbutyl group. The solid-state structure confirmed the presence of the expected isomer that had the benzothiophene at the
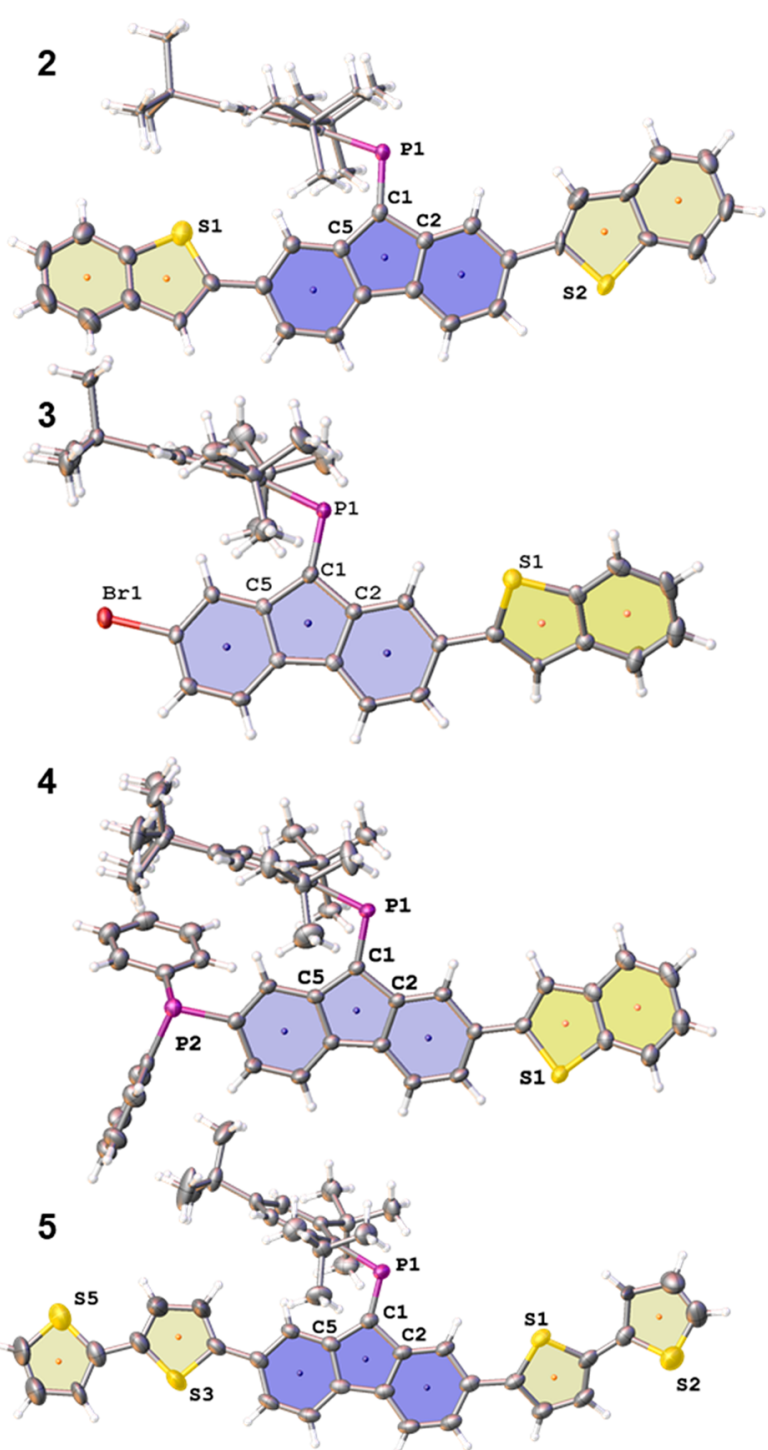

Figure 2. ORTEP-type representations of the solid-state structure of compounds 2-5 (ellipsoid probability level 50\%). Colored centroids are placed in the planes. Further details of the structure solutions can be found in the SI.

exposed position, while the bromide substituent remained in the sterically shielded position. The bond metrics were very similar to those found in 2 , with a $\mathrm{P}=\mathrm{C}$ distance of $1.685(4)$ $\AA$ and a slightly smaller $\mathrm{C}-\mathrm{P}-\mathrm{C}$ angle of $104.0(2)^{\circ}$. The $\mathrm{P}=$ $\mathrm{C}-\mathrm{C} n$ angles were $118.3(3)^{\circ}$ and $136.3(3)^{\circ}$ toward $\mathrm{C} 2$ and C5, respectively, illustrating this asymmetry. ${ }^{43}$ The $\pi$-stacking was weaker in this molecule, with only one noticeable centroid-centroid distance of 3.94 A.

The phosphine/phosphaalkene 4 had a typical phosphaalkene environment $\left(\mathrm{P}=\mathrm{C} 1.692(3) \AA, \mathrm{C}-\mathrm{P}=\mathrm{C} 105.6(1)^{\circ}\right)$, and near coplanarity between the fluorenyl and benzothiophene was observed, with a twist angle of $8.6(1)^{\circ}$ between the two least-squares planes. The diphenylphosphine moiety was rotated away from the Mes* unit, minimizing steric congestion, but otherwise had typical metrics, such as $\mathrm{P}-\mathrm{C}$ single bond distances of ca. $1.83 \AA$. The dibithiophene derivative 5 crystallized as dark red blocks in the triclinic space group $P \overline{1}$ containing four independent molecules and a solvent (DCM) in the unit cell. Most thiophene moieties-but, in particular, the terminal thienyl units-were disordered, and significantly 
lower coplanarity was seen compared to the benzothiophene derivatives. This illustrates the rotational freedom of the bithiophene substituents over the restricted benzannulated thiophene. The phosphaalkene moieties were all within the expected range of $\mathrm{P}=\mathrm{C}$ distances (1.675-1.685 $\AA$ ), and the other metrics were comparable to the other derivatives discussed herein.

Obtaining the single crystal solid-state structures of $\left[\mathrm{AuCl}^{*} 2\right]$ and $\left[\mathrm{AuCl}^{*} 3\right]$ also allowed us to study the impact of gold coordination on the bond metrics and packing in the solid state (Figure 3). Complex $\left[\mathrm{AuCl}^{*} 2\right]$ also crystallized in

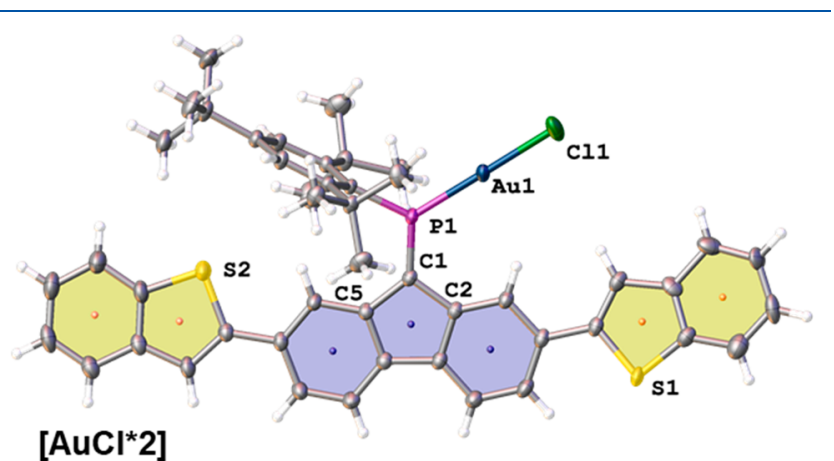

[AuCl*2]

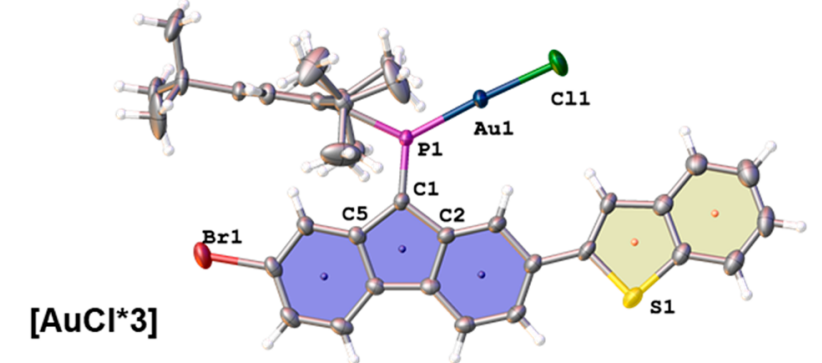

Figure 3. ORTEP-type representations ( $50 \%$ ellipsoid probabilities) of the solid-state structures of gold complexes $\left[\mathrm{AuCl}^{*} \mathbf{2}\right]$ and $\left[\mathrm{AuCl}^{*} 3\right]$. Colored centroids are placed in the planes.

the monoclinic space group $P 2_{1} / c$ as dark bluish-green needles. The $\mathrm{P}=\mathrm{C}$ bond was significantly shortened (1.672(3) $\AA$ ) compared to 2 , while the $\mathrm{C}-\mathrm{P}=\mathrm{C}$ angle became wider $\left(114.3(1)^{\circ}\right)$ as expected upon gold coordination; ${ }^{44}$ the $\mathrm{P}-$ $\mathrm{C} 1-\mathrm{C} n$ angles fell into the expected range $\left(\mathrm{C} 5=130.6(2)^{\circ}\right.$ and $\left.\mathrm{C} 2=123.5(2)^{\circ}\right)$. The $\mathrm{AuCl}$ fragment was linear, and the $\mathrm{P}-\mathrm{Au}$ distance was $2.222(1) \AA$, which is typical of phosphaalkene gold complexes. ${ }^{45,46}$ Overall, the molecular packing was very similar to that of 2 ; however, the intramolecular interactions showed increased $\pi-\pi$ interactions in $\left[\mathrm{AuCl}^{*} 2\right]$, with centroid-centroid distances in the range of 3.7-3.9 $\AA$ (2: 3.7-4.3 $\AA$ ). The benzothiophene moiety containing S1/S1B showed positional disorder with 0.63:0.37 occupancy. All benzothiophene substituents were nearly coplanar with the central fluorenyl $\pi$-system, with torsion angles between the planes being $<10^{\circ}$. Similarly, the metal coordination in $\left[\mathrm{AuCl}^{*} 3\right]$ resulted in short $\mathrm{P}=\mathrm{C}(1.675(6) \AA)$ and $\mathrm{Au}-\mathrm{P}(2.217(1) \AA)$ distances, as well as a slightly widened $\mathrm{C}-\mathrm{P}=\mathrm{C}$ angle $\left(110.8(3)^{\circ}\right)$. The $\mathrm{P}-\mathrm{C} 1-\mathrm{Cn}$ angles were $110.8(3)^{\circ}$ and $131.5(4)^{\circ}$ for $n=2$ and 5, respectively, with these values being somewhat smaller for the former and very similar for the latter compared to the complex $\left[\mathrm{AuCl}^{*} 2\right]$. Intramolecular interactions were affected by the incorporation of a solvent molecule (DCM) into the unit cell, which resulted in $\mathrm{CH}-\pi$ interactions (H-centroid distances of $2.988 \AA$ ) and weak $\pi-\pi$ interactions (centroid-centroid distances of 3.928 and $4.131 \AA$ ).

Substitution of the fluorenyl phosphaalkene with (benzo)thiophenes had a profound impact on the UV-vis absorption properties (Figure 4). While the parent dibromo-derivative 1
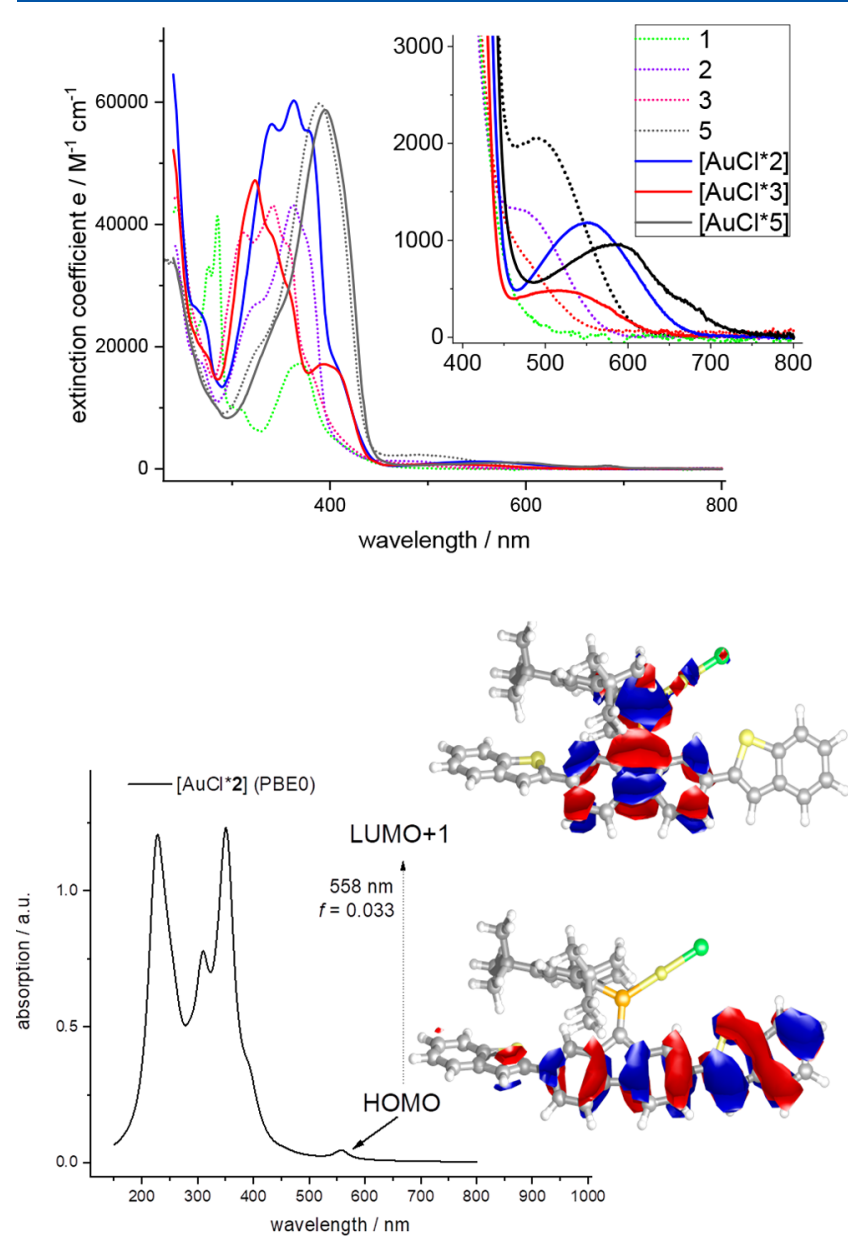

Figure 4. (Top) Experimental optical spectra of compounds 2, 3, 5, $\left[\mathrm{AuCl}^{*} 2\right],\left[\mathrm{AuCl}^{*} 3\right]$, and $\left[\mathrm{AuCl}^{*} 5\right]$ in DCM. (Bottom) An illustrative example of modeled optical transitions of $\left[\mathrm{AuCl}^{*} 2\right]$ using the TD-DFT M06-2X/6-311G**(LANL2DZ)//PBE1PBE/6$31++G^{* *}$ (LANL2DZ) level of theory. The indicated low energy transition corresponds mainly to a HOMO (extended $\pi$-fluorenyldibithiophene) to LUMO+1 (heterofulvenoid $\pi^{*}$ ) transition.

appeared yellow, with the lowest energy absorption peak being at $369 \mathrm{~nm}\left(\lambda_{\text {onset }}\right.$ ca. $\left.480 \mathrm{~nm}\right)$, these new derivatives had clearly red-shifted absorption onsets/maxima. The mono- and disubstituted derivatives 3 and $\mathbf{2}$ had very similar low energy absorptions features, with a shoulder at $486 \mathrm{~nm}$ and $\lambda_{\text {onset }}$ ca. $575 \mathrm{~nm}$; however, the extinction coefficient of this feature in 2 was almost double that of the same band in 3 (see inset in Figure 4-top, $\varepsilon=1200$ and $680 \mathrm{dm}^{3} \mathrm{~mol}^{-1} \mathrm{~cm}^{-1}$, respectively). The main absorption bands in the $\mathrm{UV}$ had similar structures but were red-shifted for $2\left(\lambda_{\max }=362 \mathrm{~nm}\right)$ compared to 3 $\left(\lambda_{\max }=341 \mathrm{~nm}\right)$. Interestingly, the dibithiophene derivative 5 showed the most red-shifted onset of absorption $(620 \mathrm{~nm})$ and low energy absorption peak (shoulder at $494 \mathrm{~nm}, \varepsilon=2050$ $\left.\mathrm{dm}^{3} \mathrm{~mol}^{-1} \mathrm{~cm}^{-1}\right)$ as well as strong bands $\left(\lambda_{\max }=389 \mathrm{~nm}\right)$. Gold(I) coordination increased the acceptor properties of the phosphaalkene moiety (see below), which is clearly reflected in the further red-shift of the maximum absorption bands. 
Complexes $\left[\mathrm{AuCl}^{*} 3\right],[\mathrm{AuCl} * 2]$, and $\left[\mathrm{AuCl}^{*} 5\right]$ have their lowest energy absorption maxima at 518, 533, and $587 \mathrm{~nm}$, respectively, corresponding to red-shifts of 32,47 , and $97 \mathrm{~nm}$, respectively. While the solubility of the free phosphaalkenes was good to excellent in organic solvents such as benzene, DCM, and chloroform, the solubility of the corresponding gold complexes of 2 and 3 dropped by at least a factor of five ( 0.5 and $0.2 \mathrm{mM}$ in $\mathrm{DCM}$, respectively). In contrast, $\left[\mathrm{AuCl}^{*} 5\right]$ had a solubility of $\gg 2 \mathrm{mM}$, suggesting that the rotational freedom of the thienyl units (cf. also disorder in the solid-state structure) had a positive impact on the solubility.

An illustrative example of the observed low energy optical transition is shown for $\left[\mathrm{AuCl}^{*} 2\right]$, with a calculated transition energy of $558 \mathrm{~nm}$ (obs. $533 \mathrm{~nm}$ ) composed mainly of a HOMO to LUMO+1 transition. The HOMO is mainly composed of the conjugated benzothiophene and fluorenyl $\pi$ orbitals, while the LUMO+1 exhibits a $\pi^{*}$ character localized on the phosphaalkene fluorenyl core. This also underlines the importance of lone pair modifications such as coordination of gold(I) chloride on the low energy transitions, with this resulting in increased acceptor character leading to the observed red-shifted maxima.

In summary, we have demonstrated the functionalization of fluorenyl phosphaalkenes using heteroaromatic stannyl reagents. The steric shielding provided by the Mes* substituent led to distinctively different reactivities for the $\mathrm{C} 2-\mathrm{Br}$ and $\mathrm{C} 7-\mathrm{Br}$ sites, allowing us to introduce a strong asymmetry into the system. Further functionalization was achieved by coordination of gold to the phosphorus center, resulting in bathochromically shifted low energy absorption maxima and onsets.

\section{EXPERIMENTAL SECTION}

Materials and Measurements. Except where otherwise stated, reagents were purchased from Sigma-Aldrich and VWR and were used without any further purification. All reactions were performed under argon using flame-dried glassware and standard Schlenk techniques. THF and diethyl ether were dried over sodium benzophenone; DCM was dried over $\mathrm{CaCl}_{2}$. All solvents were freshly distilled prior to use. Microwave reactions were carried out in a CEM Biotage Initiator reactor, and reaction temperature was monitored using the built-in IR sensor. Temperature profiles and durations are provided for the individual reactions. NMR spectra were recorded using a JEOL spectrometer $\left({ }^{1} \mathrm{H}\right.$ frequency $\left.400 \mathrm{MHz}\right)$. High-resolution mass spectra were measured using FTMS $+p$ APCI or FTMS $+p$ NSI (OrbitrapXL) at the University of Münster. UV/vis spectra were recorded on a Varian Cary 50 or 50000 diodearray spectrophotometers.

X-ray Crystallography. All the measurements were performed using graphite-monochromatized $\mathrm{Mo}_{\alpha}$ radiation at $150 \mathrm{~K}$ using a Bruker D8 APEX-II equipped with a CCD camera. The structure was solved by direct methods (SHELXS-2014) and refined by full-matrix least-squares techniques against $F^{2}$ (SHELXL-2018). ${ }^{47,48}$ The nonhydrogen atoms were refined with anisotropic displacement parameters. The $\mathrm{H}$ atoms of the $\mathrm{CH}_{2}$ groups were refined with common isotropic displacement parameters for the $\mathrm{H}$ atoms of the same group and idealized geometry with approximately tetrahedral angles and $\mathrm{C}-\mathrm{H}$ distances of $0.99 \AA$. The $\mathrm{H}$ atoms of the methyl groups were refined with common isotropic displacement parameters for the $\mathrm{H}$ atoms of the same group and idealized geometry with tetrahedral angles, enabling rotation around the $\mathrm{X}-\mathrm{C}$ bond, and $\mathrm{C}-\mathrm{H}$ distances of $0.98 \AA$. Additional details can be found in the cif files. Analysis of solid-state structures was carried out using Conquest. ${ }^{49}$ Calculations are performed using the Gaussian suite of programs (G09 Rev D.01) ${ }^{50}$ The structures are optimized at the DFT M06-2X level of theory using a $6-311 \mathrm{G}^{* *}$ basis set and the LANL2DZ pseudo potential for Au. TD-DFT calculations are carried out using an extended basis set $\left(6-311++\mathrm{G}^{* *} / \mathrm{LANL} 2 \mathrm{DZ}\right.$. Among all tested functionals the best agreement with experimental UV/vis data was found for the PBE1PBE functional.

Synthesis of 2 and 3. Dibromo phosphaalkene 1 (108 mg, 0.18 mmol) and tributylstannylbenzothiophene $(252 \mathrm{mg}, 0.59 \mathrm{mmol}, 3.2$ equiv) were dissolved in $2 \mathrm{~mL}$ of THF (deaerated for $30 \mathrm{~min}$ ) followed by addition of $\left[\mathrm{Pd}\left(\mathrm{PPh}_{3}\right)_{4}\right](22 \mathrm{mg}, \sim 2 \% \mathrm{~mol})$. The microwave tube was sealed under argon after degassing for $5 \mathrm{~min}$, and then the vial was placed in the microwave reactor (CEM, Biotage) at $120^{\circ} \mathrm{C}$ for $45 \mathrm{~min}$. The crude reaction mixture was filtered through a thin pad of Celite (top) and silica (bottom) and concentrated under reduced pressure to yield a crude solid. The crude was dry-loaded into a column and eluted using a DCM:pentane gradient (1\% to $10 \%)$ to yield $2\left(\mathrm{R}_{\mathrm{f}}=0.55,5 \%\right)$ and $3\left(\mathrm{R}_{\mathrm{f}}=0.11,5 \%\right)$ as a dark red solids. Single crystals of both compounds were obtained by slow evaporation of the solvents.

2: ${ }^{1} \mathrm{H}$ NMR $\left(400 \mathrm{MHz}, \mathrm{CDCl}_{3}\right) \delta 8.63(\mathrm{~d}, J=3.7 \mathrm{~Hz}, 1 \mathrm{H}), 7.89-$ $7.85(\mathrm{~m}, 1 \mathrm{H}), 7.82(\mathrm{dd}, J=7.1,1.1 \mathrm{~Hz}, 1 \mathrm{H}), 7.76-7.70(\mathrm{~m}, 4 \mathrm{H})$, $7.69-7.63(\mathrm{~m}, 3 \mathrm{H}), 7.57(\mathrm{~d}, J=7.9 \mathrm{~Hz}, 1 \mathrm{H}), 7.38(\mathrm{td}, J=7.5,1.3 \mathrm{~Hz}$, $1 \mathrm{H}), 7.33(\mathrm{tt}, J=7.8,1.5 \mathrm{~Hz}, 2 \mathrm{H}), 7.29(\mathrm{dd}, J=7.7,1.5 \mathrm{~Hz}, 1 \mathrm{H})$, 7.17-7.10 (m, 1H), $6.46(\mathrm{~s}, 1 \mathrm{H}), 1.50(\mathrm{~s}, 18 \mathrm{H}), 1.41(\mathrm{~s}, 9 \mathrm{H})$. ${ }^{13} \mathrm{C}\left\{{ }^{1} \mathrm{H}\right\}$ NMR $\left(101 \mathrm{MHz}, \mathrm{CDCl}_{3}\right) \delta 154.1,151.7,144.9,144.7$, $140.9,140.7,139.5$ (d, $J=14.4 \mathrm{~Hz}), 133.9,133.3,133.5,133.3-133.0$ (3-4 peaks), $128.8(\mathrm{~d}, J=5.2 \mathrm{~Hz}), 128.6(\mathrm{~d}, J=6.9 \mathrm{~Hz}), 127.2(\mathrm{~m}$, 2-3 peaks)126.6 ( 2 d, ca. $5.9 \mathrm{~Hz}), 124.7$ (m, min. 3 peaks), 124.4 (d, $J$ $=6.0 \mathrm{~Hz}), 124.2,123.6(\mathrm{~d}, J=7.0 \mathrm{~Hz}), 123.2(2$ peaks $), 122.4,122.1$, 120.1 ( 2 peaks), 119.7 ( 2 peaks), 119.5, $118.4(\mathrm{~d}, J=24.5 \mathrm{~Hz}$; maybe 2 peaks), 38.6, 35.4, $32.8(\mathrm{~d}, J=6.3 \mathrm{~Hz}), 31.5$. (Several carbon resonances including the $\mathrm{P}=\mathrm{C}$ could not be detected due to small quantities and insufficient resolution.) ${ }^{31} \mathrm{P}\left\{{ }^{1} \mathrm{H}\right\} \mathrm{NMR}(162 \mathrm{MHz}$, $\mathrm{CDCl}_{3}$ ) $\delta$ 268.4. HR-MS (APCI) $\mathrm{m} / z=\mathrm{M}^{+}$Calcd for $\mathrm{C}_{47} \mathrm{H}_{45} \mathrm{PS}_{2}$ 704.2695; Found 704.2693; $[\mathrm{M}+\mathrm{H}]^{+}$: Calcd for $\mathrm{C}_{47} \mathrm{H}_{46} \mathrm{PS}_{2}$ 705.2773; Found 705.2727. Yield: $5 \mathrm{mg}$.

3: ${ }^{1} \mathrm{H}$ NMR $\left(400 \mathrm{MHz}, \mathrm{CDCl}_{3}\right) \delta 8.58(\mathrm{~d}, J=3.4 \mathrm{~Hz}, 1 \mathrm{H}), 7.85$ (d, $J=7.8 \mathrm{~Hz}, 1 \mathrm{H}), 7.80(\mathrm{~d}, J=7.3 \mathrm{~Hz}, 1 \mathrm{H}), 7.69(\mathrm{~d}, J=8.5 \mathrm{~Hz}, 2 \mathrm{H})$, $7.63(\mathrm{~s}, 1 \mathrm{H}), 7.61(\mathrm{~s}, 3 \mathrm{H}), 7.42(\mathrm{~d}, J=8.1 \mathrm{~Hz}, 1 \mathrm{H}), 7.37(\mathrm{td}, J=7.5$ $1.3 \mathrm{~Hz}, 1 \mathrm{H}), 7.32(\mathrm{td}, J=7.5,1.5 \mathrm{~Hz}, 1 \mathrm{H}), 7.28(\mathrm{~d}, J=8.2 \mathrm{~Hz}, 1 \mathrm{H})$, $5.43(\mathrm{~s}, 1 \mathrm{H}), 1.46(\mathrm{~s}, 9 \mathrm{H}), 1.44(\mathrm{~s}, 18 \mathrm{H}) .{ }^{13} \mathrm{C}\left\{{ }^{1} \mathrm{H}\right\}$ NMR $(101 \mathrm{MHz}$, $\left.\mathrm{CDCl}_{3}\right) \delta 167.4(\mathrm{~d}, 44.9 \mathrm{~Hz}), 154.2,152.3,144.6,140.9,139.6,133.3$ (d, $J=26.4 \mathrm{~Hz}), 131.0(\mathrm{~d}, J=5.9 \mathrm{~Hz}), 129.4(\mathrm{~d}, J=7.7 \mathrm{~Hz}), 127.2$, 126.6 (2 peaks), 124.7, 124.4, 123.6, 123.1 (2 peaks), 122.4, 120.4 (2 peaks), 120.0, 119.6, 118.4, 118.2(2 peaks), 38.4, 35.4, 32.9 (d, $J=6.8$ $\mathrm{Hz})$, 31.6. ${ }^{31} \mathrm{P}\left\{{ }^{1} \mathrm{H}\right\}$ NMR (162 $\left.\mathrm{MHz}, \mathrm{CDCl}_{3}\right) \delta$ 269.6. HR-MS (APCI) $m / z=[\mathrm{M}+\mathrm{H}]^{+}$Calcd for $\mathrm{C}_{39} \mathrm{H}_{41} \mathrm{BrPS}: 651.1845$ and 653.183; Found 651.1835 and 653.1813; $\mathrm{M}^{+}$: Calcd for $\mathrm{C}_{39} \mathrm{H}_{40} \mathrm{BrPS}$ 650.1766 and 652.1752; Found 650.17686 and 652.17690 (Br isotope pattern). yield: $23 \mathrm{mg}$.

Synthesis of 5. Dibromo-phosphaalkene 1 ( $0.084 \mathrm{~g}, 1$ equiv), [2,2'-bithiophen]-5-yltributylstannane $2(0.1920 \mathrm{~g}, 3$ equiv, [Pd$\left.\left(\mathrm{PPh}_{3}\right)_{4}\right], 3$ (27 mg, 0.017 equiv $\left.\sim 17 \% \mathrm{~mol}\right)$, and THF $(2 \mathrm{~mL})$ were added to a dry microwave tube under argon. The solution was deaerated by thoroughly bubbling with argon for $45 \mathrm{~min}$, and the capped tube was placed in a microwave reactor at $120^{\circ} \mathrm{C}$ for $45 \mathrm{~min}$. The crude reaction mixture was filtered through a thin pad of Celite (top) and silica (bottom) into a round-bottom flask using a glasssintered frit and concentrated under reduced pressure to yield a crude solid. The crude was dry-loaded into a column and eluted using a 95:5 pentane: $\mathrm{Et}_{2} \mathrm{O}$ mixture $\left(\mathrm{R}_{\mathrm{f}}: 0.3\right)$ to yield $\mathbf{5}$ as a dark red solid. Single crystals were obtained from diffusion of a $1: 1$ pentane: $\mathrm{Et}_{2} \mathrm{O}$ mixture into a vial of 5 dissolved in DCM (yield $=15.2 \mathrm{mg}, 14 \%$ ).

${ }^{1} \mathrm{H}$ NMR (400 MHz, THF-d8) $\delta 8.47(\mathrm{~d}, J=3.8 \mathrm{~Hz}=1 \mathrm{H}), 7.70-$ $7.61(\mathrm{~m}, 5 \mathrm{H}), 7.45(\mathrm{~d}, J=3.8 \mathrm{~Hz}, 1 \mathrm{H}), 7.40(\mathrm{dm}, J=8.1 \mathrm{~Hz}, 1 \mathrm{H})$, 7.31 (ddd, $J=5.1,2.6,1.2 \mathrm{~Hz}, 2 \mathrm{H}), 7.28(\mathrm{dd}, J=3.6,1.2 \mathrm{~Hz}, 1 \mathrm{H})$, $7.23(\mathrm{~d}, J=3.8 \mathrm{~Hz}, 1 \mathrm{H}), 7.18(\mathrm{dd}, J=3.6,1.2 \mathrm{~Hz}, 1 \mathrm{H}), 7.05-6.96$ $(\mathrm{m}, 3 \mathrm{H}), 6.66(\mathrm{~d}, J=3.7 \mathrm{~Hz}, 1 \mathrm{H}), 6.35(\mathrm{~m}, 1 \mathrm{H}), 1.48(\mathrm{~s} 18 \mathrm{H}), 1.39$ (s, 9H). ${ }^{13} \mathrm{C}\left\{{ }^{1} \mathrm{H}\right\}$ NMR $\left(101 \mathrm{MHz}, \mathrm{CDCl}_{3}\right) \delta 167.6(\mathrm{~d}, J=43.1 \mathrm{~Hz})$, $154.3,151.6,144.3,144.1,143.8,143.6,139.6,139.4,138.5$ (d, $J=9.7$ $\mathrm{Hz}), 137.7,137.4,137.0,136.9,136.2,133.6(\mathrm{~d}, J=58.0 \mathrm{~Hz}), 133.0$, $132.5,128.0(\mathrm{~d}, J=9.2 \mathrm{~Hz}), 126.5(\mathrm{~d}, J=5.4 \mathrm{~Hz}), 125.8(\mathrm{~d}, J=6.3$ 
$\mathrm{Hz}), 124.7$ (d, $J=7.9 \mathrm{~Hz}), 124.4$ (d, $J=3.0 \mathrm{~Hz}), 123.9,123.8,123.7$, 123.6, 123.2 (d, $J=7.5 \mathrm{~Hz}$ ), 123.1, 120.0, 119.6, 117.6, 117.4, 38.6, 35.4, $32.7(\mathrm{~d}, J=6.4 \mathrm{~Hz}), 31.5 .{ }^{31} \mathrm{P}\left\{{ }^{1} \mathrm{H}\right\}$ NMR $(162 \mathrm{MHz}$, THF-d8) $\delta$ 263.9. HR-MS (APCI) $m / z=\mathrm{M}^{+}$Calcd for $\mathrm{C}_{47} \mathrm{H}_{45} \mathrm{PS}_{4}$ 768.2136; Found 768.2130; $[\mathrm{M}+\mathrm{H}]^{+}$: Calcd for $\mathrm{C}_{47} \mathrm{H}_{46} \mathrm{PS}_{4}$ 769.2215; Found 769.2186. yield: $15.2 \mathrm{mg}, 14 \%$.

Characterization of $6 .{ }^{29,51}{ }^{1} \mathrm{H} \mathrm{NMR}\left(400 \mathrm{MHz}, \mathrm{CDCl}_{3}\right) \delta 8.50$ $(\mathrm{d}, J=4.2 \mathrm{~Hz}, 1 \mathrm{H}), 7.64(\mathrm{~s}, 3 \mathrm{H}), 7.60(\mathrm{~d}, J=5.0 \mathrm{~Hz}, 1 \mathrm{H}), 7.59(\mathrm{~s}$, $1 \mathrm{H}), 7.47(\mathrm{dd}, J=3.5,1.3 \mathrm{~Hz}, 1 \mathrm{H}), 7.42(\mathrm{~d}, J=8.1 \mathrm{~Hz}, 1 \mathrm{H}), 7.33(\mathrm{dd}$, $J=5.1,1.3 \mathrm{~Hz}, 1 \mathrm{H}), 7.29(\mathrm{~d}, J=8.2 \mathrm{~Hz}, 1 \mathrm{H}), 7.14(\mathrm{dd}, J=5.1,3.7$ $\mathrm{Hz}, 1 \mathrm{H}), 5.47-5.42(\mathrm{~m}, 1 \mathrm{H}), 1.50(\mathrm{~s}, 9 \mathrm{H}), 1.47(\mathrm{~s}, 18 \mathrm{H}) .{ }^{13} \mathrm{C}\left\{{ }^{1} \mathrm{H}\right\}$ NMR $\left(101 \mathrm{MHz}, \mathrm{CDCl}_{3}\right) \delta 167.7(\mathrm{~d}, J=44.1 \mathrm{~Hz}), 154.2(\mathrm{~d}, J=0.7$ $\mathrm{Hz}), 152.3,144.8,143.5$ (d, $J=26.5 \mathrm{~Hz}), 140.0(\mathrm{~d}, J=16.7 \mathrm{~Hz})$, $137.7(\mathrm{~d}, J=10.3 \mathrm{~Hz}), 136.5(\mathrm{~d}, J=14.0 \mathrm{~Hz}), 133.7(\mathrm{~d}, J=2.7 \mathrm{~Hz})$, $131.0(\mathrm{~d}, J=6.2 \mathrm{~Hz}), 129.4(\mathrm{~d}, J=7.5 \mathrm{~Hz}), 128.2,126.2(\mathrm{~d}, J=6.6$ $\mathrm{Hz}), 124.9,123.4,123.0,120.7$ (d, $J=4.2 \mathrm{~Hz}), 120.3(\mathrm{~d}, J=2.9 \mathrm{~Hz})$, $120.0,117.9(\mathrm{~d}, J=24.4 \mathrm{~Hz}), 38.4,35.4,32.9(\mathrm{~d}, J=6.8 \mathrm{~Hz}), 31.7$. ${ }^{31} \mathrm{P}\left\{{ }^{1} \mathrm{H}\right\}$ NMR $\left(162 \mathrm{MHz}, \mathrm{CDCl}_{3}\right) \delta$ 268.4. HR-MS (APCI) $\mathrm{m} / z=$ $\mathrm{M}^{+}$Calcd for $\mathrm{C}_{35} \mathrm{H}_{38} \mathrm{BrPS} 600.1610$ and 602.1589; Found 600.1610 and 602.1579; $[\mathrm{M}+\mathrm{H}]^{+}$: Calcd for $\mathrm{C}_{35} \mathrm{H}_{39} \mathrm{BrPS} 601.1688$ and 603.1668; Found 601.1667 and 603.1643 ( $\mathrm{Br}$ isotope pattern).

Synthesis of 7. Compound $1(184 \mathrm{mg}, 0.52 \mathrm{mmol})$ was added to 2 -( $\left(\mathrm{Bu}_{3} \mathrm{Sn}\right)$-pyridine $(500 \mu \mathrm{L}, 1.54 \mathrm{mmol})$ in $10 \mathrm{~mL}$ of THF, and the solution was degassed for $30 \mathrm{~min}$. After adding $\left[\mathrm{Pd}\left(\mathrm{PPh}_{3}\right)_{4}\right](130 \mathrm{mg}$, $0.1 \mathrm{mmol}, 10 \mathrm{~mol} \%)$ an immediate color change to dark blue occurred, and the sealed vial was placed in a microwave reactor for 45 min at $140{ }^{\circ} \mathrm{C}$. The crude reaction mixture was passed through an alumina plug. Chromatographic workup (silica hexane/toluene) gave a relatively pure fraction of the mixed phosphine oxide phosphaalkene species. The splitting of the low frequency aromatic proton $(6.36$ $\mathrm{ppm})$ indicates that the phosphine is in the sterically more shielded position, leading to a 3-bond $\mathrm{P}-\mathrm{H}$ coupling $\left({ }^{3} \mathrm{~J}_{\mathrm{PH}}=11.0 \mathrm{~Hz}\right)$.

${ }^{1} \mathrm{H}$ NMR $\left(400 \mathrm{MHz}, \mathrm{CDCl}_{3}\right) \delta 9.51(\mathrm{~d}, J=3.2,1 \mathrm{H}), 8.67(\mathrm{~d}, J=$ $4.6 \mathrm{~Hz}, 1 \mathrm{H}), 8.27(\mathrm{~d}, J=8.2 \mathrm{~Hz}, 1 \mathrm{H}), 7.63(2 \mathrm{H}), 7.55$ (ps. tr., $J=7.8$ $\mathrm{Hz}, 1 \mathrm{H}), 7.50-7.44(\mathrm{~m}, 3 \mathrm{H}), 7.39(1 \mathrm{H}), 7.35-7.27(\mathrm{~m}, 4 \mathrm{H}), 7.14-$ $7.08(\mathrm{~m}, 4 \mathrm{H}), 6.99(\mathrm{~m}, 1 \mathrm{H}), 6.70(\mathrm{dd}, J=6.93 .4 \mathrm{~Hz}, 1 \mathrm{H}), 6.36(\mathrm{~d}, J$ $=11.0 \mathrm{~Hz}, 1 \mathrm{H}), 1.52(9 \mathrm{H}), 1.49(18 \mathrm{H}) \cdot{ }^{31} \mathrm{P}\left\{{ }^{1} \mathrm{H}\right\} \operatorname{NMR}(162 \mathrm{MHz}$, $\left.\mathrm{CDCl}_{3}\right) \delta 263.6(\mathrm{P}=\mathrm{C}),-3.9\left(-\mathrm{PPh}_{2}\right)$ ppm. Satisfactory ${ }^{13} \mathrm{C}\left\{{ }^{1} \mathrm{H}\right\}$ data and other analysis could not be obtained.

In an attempt to identify how the diphenylphosphine transfer occurred, we reacted $1(200 \mathrm{mg}, 0.56 \mathrm{mmol})$ in the presence of excess $\mathrm{PPh}_{3}(450 \mathrm{mg}, 1.7 \mathrm{mmol})$ and $\left[\mathrm{Pd}\left(\mathrm{PPh}_{3}\right)_{4}\right](150 \mathrm{mg}, 0.13 \mathrm{mmol})$. The reaction solvent was THF, and the microwave was set to $165{ }^{\circ} \mathrm{C}$ for $90 \mathrm{~min}$. The phosphine oxide was isolated in a mixture with $\mathrm{OPPh}_{3}$. Diagnostic peaks in the phosphorus and proton NMR indicate the formation of the mixed phosphine phosphaalkene species 8. Based on the absence of a substantial ${ }^{3} \mathrm{~J}_{\mathrm{PH}}$ coupling of the low frequency aromatic proton (br. s. $5.19 \mathrm{ppm}$ ), we assume that the coupling occurred at the less hindered position.

Selected NMR shifts: ${ }^{1} \mathrm{H}$ NMR $\left(400 \mathrm{MHz}, \mathrm{CDCl}_{3}\right) \delta 7.02$ (d, $J=$ $8.0 \mathrm{~Hz}, 1 \mathrm{H}), 6.61(\mathrm{~m}, 2 \mathrm{H}), 6.44(\mathrm{~d}, J=7.9 \mathrm{~Hz}, 1 \mathrm{H}), 6.21$ (ps. t $J=$ $7.8 \mathrm{~Hz}, 1 \mathrm{H}) 5.19$ (br. s., $1 \mathrm{H}), 1.43(9 \mathrm{H}), 1.35(18 \mathrm{H}) .{ }^{31} \mathrm{P}\left\{{ }^{1} \mathrm{H}\right\}$ NMR $\left(162 \mathrm{MHz}, \mathrm{CDCl}_{3}\right) \delta 256.9(\mathrm{P}=\mathrm{C}), 24.0\left(-\mathrm{P}(=\mathrm{O}) \mathrm{Ph}_{2}\right) \mathrm{ppm}$.

Synthesis of $[\mathrm{AuCl} * 2]$. A solution of $2(11.65 \mathrm{mg}, 0.0254 \mathrm{mmol})$ in $3 \mathrm{~mL}$ of DCM was mixed with 1 equiv of a [ $\mathrm{AuCl}(\mathrm{tht})]$ solution $(8.14 \mathrm{mg})$, stirred for $2 \mathrm{~h}$, and then filtered over Celite. The solvent was slowly evaporated, and all remaining volatiles were removed under reduced pressure. The product was collected as crystalline material in $96 \%$ yield.

${ }^{1} \mathrm{H}$ NMR $\left(400 \mathrm{MHz}, \mathrm{CDCl}_{3}\right) \delta 9.33(\mathrm{~d}, J=4.4 \mathrm{~Hz}, 1 \mathrm{H}), 7.95(\mathrm{~s}$, $1 \mathrm{H}), 7.04(\mathrm{t}, J=13.3,2 \mathrm{H}), 7.67-7.59(\mathrm{~m}, 3 \mathrm{H}), 7.38-7.28(\mathrm{~m}, 4 \mathrm{H})$, $7.17(\mathrm{~s}, 1 \mathrm{H}), 6.41(\mathrm{~d}, J=3.2 \mathrm{~Hz}, 1 \mathrm{H}), 1.67(\mathrm{~s}, 18 \mathrm{H}), 1.40(\mathrm{~s}, 9 \mathrm{H})$. ${ }^{13} \mathrm{C}\left\{{ }^{1} \mathrm{H}\right\}$ NMR $\left(101 \mathrm{MHz}, \mathrm{CDCl}_{3}\right) \delta 158.6(\mathrm{~d}, J=79.0 \mathrm{~Hz}) 155.8$, 155.5, 143.6, 142.9, 141.0, 140.5, 139.9, 139.6 (2 peaks), 139.4, 139.3, $139.2,138.0,137.8,134.6,134.6,133.7,133.7,129.0-128.8(\mathrm{~d}, 2$ peaks), $125.4(\mathrm{~d}, J=9.6 \mathrm{~Hz}), 124.7,124.7,124.4(\mathrm{~d}, J=10.1 \mathrm{~Hz})$, $124.3,123.7,122.2$ (d, $J=19.3), 120.9,120.6$ (2 peaks), 119.8 (d, $J=$ $21.0 \mathrm{~Hz}), 119.4,39.6,35.7,34.3,31.2 \mathrm{ppm} .{ }^{31} \mathrm{P}\left\{{ }^{1} \mathrm{H}\right\}$ NMR $(162$ $\mathrm{MHz}, \mathrm{CDCl}_{3}$ ) $\delta 181.4$ ppm. HR-MS (MALDI) $m / z=\mathrm{M}+\mathrm{Au}^{+}$Calcd for $\mathrm{C}_{47} \mathrm{H}_{45} \mathrm{PS}_{2} \mathrm{Au}_{2} \mathrm{Cl}$ 1133.1715; Found 1133.1708.
Synthesis of $[\mathrm{AuCl} * 3]$. A solution of $3(23.44 \mathrm{mg}, 0.058 \mathrm{mmol})$ in $3 \mathrm{~mL}$ of DCM was mixed with 1 equiv of a $[\mathrm{AuCl}(\mathrm{tht})]$ solution $(18.7 \mathrm{mg})$, stirred for $2 \mathrm{~h}$, and then filtered over Celite. The solvent was slowly evaporated, and all remaining volatiles were removed under reduced pressure. The product was collected as crystalline material in $98 \%$ yield.

${ }^{1} \mathrm{H}$ NMR $\left(400 \mathrm{MHz}, \mathrm{CDCl}_{3}\right) \delta 9.91(\mathrm{~d}, J=5.3 \mathrm{~Hz}, 1 \mathrm{H}), 7.94$ $(1 \mathrm{H}), 7.89(\mathrm{~d}, J=7.3 \mathrm{~Hz}, 1 \mathrm{H}), 7.84(\mathrm{~d}, J=7.8 \mathrm{~Hz}, 1 \mathrm{H}), 7.77(\mathrm{~d}, J=$ $4.1 \mathrm{~Hz}, 2 \mathrm{H}), 7.75(\mathrm{~m}, 1 \mathrm{H}), 7.59(\mathrm{dd}, J=8.0,18 \mathrm{~Hz}, 1 \mathrm{H}), 7.40-7.30$ $(\mathrm{m}, 4 \mathrm{H}), 5.27(\mathrm{~d}, J=3.4 \mathrm{~Hz}, 1 \mathrm{H}), 1.62(\mathrm{~s}, 18 \mathrm{H}), 1.46(\mathrm{~s}, 9 \mathrm{H})$. ${ }^{13} \mathrm{C}\left\{{ }^{1} \mathrm{H}\right\} \operatorname{NMR}\left(101 \mathrm{MHz}, \mathrm{CDCl}_{3}\right) \delta 158.8(\mathrm{~d}, J=80.1 \mathrm{~Hz}), 156.3$, $142.7,141.0,140.5(\mathrm{~d}, J=13.6 \mathrm{~Hz}), 139.6,139.0(\mathrm{~d}, J=5.8 \mathrm{~Hz})$, $138.3,138.0,137.8,137.6,134.7(\mathrm{~d}, J=4.8 \mathrm{~Hz}), 133.1(\mathrm{~d}, J=7.7$ $\mathrm{Hz}), 129.1(\mathrm{~d}, J=9.6 \mathrm{~Hz}), 128.9(\mathrm{~d}, J=7.7 \mathrm{~Hz}), 125.2(\mathrm{~d}, J=10.6$ $\mathrm{Hz}), 124.7,124.3,122.3,121.9(\mathrm{~d}, J=33.7 \mathrm{~Hz}), 123.3(\mathrm{~d}, J=6.7 \mathrm{~Hz})$, $121.2(\mathrm{~d}, J=3.0 \mathrm{~Hz}), 121.0,120.5,119.7$ (d, $J=20.2 \mathrm{~Hz}), 39.4,35.8$, 34.3, 31.3, 30.7. (Ortho and meta positions of the Mes* are not magnetically equivalent.) ${ }^{31} \mathrm{P} \mathrm{NMR}\left(162 \mathrm{MHz}, \mathrm{CDCl}_{3}\right) \delta 182.5 \mathrm{ppm}$. HR-MS (MALDI) $m / z=\mathrm{M}+\mathrm{Au}^{+}$Calcd for $\mathrm{C}_{39} \mathrm{H}_{40} \mathrm{PBrSAu}_{2} \mathrm{Cl}$ 1081.0769; Found 1081.0757.

Synthesis of $[A u C l * 5]$. A solution of $5(7.15 \mathrm{mg}, 0.0137 \mathrm{mmol})$ in $3 \mathrm{~mL}$ of DCM was mixed with 1 equiv of a [ $\mathrm{AuCl}(\mathrm{tht})]$ solution $(8.14 \mathrm{mg})$, stirred for $2 \mathrm{~h}$, and then filtered over Celite. The solvent was slowly evaporated, and all remaining volatiles were removed under reduced pressure. The product was collected as crystalline material in $82 \%$ yield.

${ }^{1} \mathrm{H}$ NMR (400 MHz, $\left.\mathrm{CDCl}_{3}\right) \delta 9.74(\mathrm{~d}, J=4.4 \mathrm{~Hz}, 1 \mathrm{H}), 7.79(\mathrm{~d}, J$ $=3.9 \mathrm{~Hz}, 2 \mathrm{H}), 7.69(\mathrm{~m} \mathrm{1H}), 7.58(\mathrm{~d}, J=8.0 \mathrm{~Hz}, 1 \mathrm{H}), 7.53(\mathrm{~d}, J=3.7$ $\mathrm{Hz}, 1 \mathrm{H}) 7.51(\mathrm{~s}, 1 \mathrm{H}), 7.44(\mathrm{dm}, J=7.8 \mathrm{~Hz}, 1 \mathrm{H}), 7.27$ (dd, $J=3.7$ and $0.9 \mathrm{~Hz}, 1 \mathrm{H}), 7.24-7.21(\mathrm{~m}, 4 \mathrm{H}) 7.14(\mathrm{dd}, J=3.4$ and $0.9 \mathrm{~Hz}$ $1 \mathrm{H}), 7.03$ (ps. q. $J=4.9 \mathrm{~Hz}, 2 \mathrm{H}), 6.97(\mathrm{~d}, J=3.7 \mathrm{~Hz}, 1 \mathrm{H}), 6.54(\mathrm{~d}, J$ $=3.9 \mathrm{~Hz}, 1 \mathrm{H}) 1.65(\mathrm{~s}, 18 \mathrm{H}), 1.37(\mathrm{~s}, 9 \mathrm{H}) \cdot{ }^{13} \mathrm{C}\left\{{ }^{1} \mathrm{H}\right\}$ NMR $(101 \mathrm{MHz}$, $\left.\mathrm{CDCl}_{3}\right) \delta 166.3(\mathrm{~d}, J=30 \mathrm{~Hz}), 156.1(\mathrm{~d}, J=79.0 \mathrm{~Hz}) 155.5,142.7$, $141.9,139.9,139.8,139.5,139.2,138.7(\mathrm{~d}, J=17.3 \mathrm{~Hz}, 2 \mathrm{C}) 137.5$, $137.3,137.0(\mathrm{~d}, J=2.9 \mathrm{~Hz}) 134.2,134.2,133.2(\mathrm{~d}, J=5.8 \mathrm{~Hz}), 128.3$ $(\mathrm{d}, J=7.7 \mathrm{~Hz}), 128.0(\mathrm{~d}, J=9.6 \mathrm{~Hz}), 127.8(\mathrm{~d}, J=8.7 \mathrm{~Hz}), 125.3$, $125.2(\mathrm{~d}, J=6.7 \mathrm{~Hz}), 124.8(\mathrm{~d}, J=7.7 \mathrm{~Hz}), 124.6(\mathrm{~d}, J=6.7 \mathrm{~Hz})$, 124.1 (d, $J=7.7 \mathrm{~Hz}$ ), 123.7, 123.0 (ps. $\mathrm{m}, 2 \mathrm{C}$ ) $120.5,119.0$ (d, $J=$ $21.2 \mathrm{~Hz}$ ), 39.6, 35.7, 34.3, 31.2, 30.7. (Ortho and meta positions of the Mes* are not magnetically equivalent.) ${ }^{31} \mathrm{P}\left\{{ }^{1} \mathrm{H}\right\} \mathrm{NMR}(162 \mathrm{MHz}$, $\mathrm{CDCl}_{3}$ ) $\delta 179.6 \mathrm{ppm}$. HR-MS (MALDI) $\mathrm{m} / z=\mathrm{M}+\mathrm{Au}^{+}$Calcd for $\mathrm{C}_{47} \mathrm{H}_{44} \mathrm{PS}_{4} \mathrm{Au}_{2} \mathrm{Cl}$ 1197.1156; Found 1197.1154.

\section{ASSOCIATED CONTENT}

\section{Supporting Information}

The Supporting Information is available free of charge at https://pubs.acs.org/doi/10.1021/acs.joc.0c01336.

Experimental data (NMR spectroscopic and crystallographic data) (PDF)

NMR spectra of synthesized compounds and additional calculations (PDF)

CIF file (CIF)

\section{AUTHOR INFORMATION}

\section{Corresponding Author}

Andreas Orthaber - Synthetic Molecular Chemistry, Department of Chemistry - Angström Laboratories, Uppsala University, 75120 Uppsala, Sweden; ㅇo orcid.org/0000-00015403-9902; Email: andreas.orthaber@kemi.uu.se

\section{Authors}

Joshua P. Green - Synthetic Molecular Chemistry, Department of Chemistry - Angström Laboratories, Uppsala University, 75120 Uppsala, Sweden

Daniel Morales Salazar - Synthetic Molecular Chemistry, Department of Chemistry - Ångström Laboratories, Uppsala University, 75120 Uppsala, Sweden 
Arvind Kumar Gupta - Synthetic Molecular Chemistry, Department of Chemistry - Ångström Laboratories, Uppsala University, 75120 Uppsala, Sweden

Complete contact information is available at: https://pubs.acs.org/10.1021/acs.joc.0c01336

\section{Notes}

The authors declare no competing financial interest. Supporting research data quoting CCDC numbers 1869034, 1869036, and 1994640-1994643 for this article may be accessed free of charge from The Cambridge Crystallographic Data Centre at www.ccdc.cam.ac.uk/structures .

\section{ACKNOWLEDGMENTS}

We would like to thank the members of the COST action "Smart Inorganic Polymers" (SIPs) and in particular the chair Prof. Hey-Hawkins and the working group leaders for their efforts to create this stimulating network. The authors would like to thank the Swedish research council (Vetenskapsrådet), the Olle-Engkvist foundation, the Lars-Hiertas-minne, and the Carl-Trygger foundation for their financial support.

\section{REFERENCES}

(1) Murphy, A. R.; Fréchet, J. M. J. Organic Semiconducting Oligomers for Use in Thin Film Transistors. Chem. Rev. 2007, 107 (4), 1066-1096.

(2) Roncali, J. Synthetic Principles for Bandgap Control in Linear $\pi$ Conjugated Systems. Chem. Rev. 1997, 97 (1), 173-206.

(3) Duan, L.; Qiao, J.; Sun, Y.; Qiu, Y. Strategies to Design Bipolar Small Molecules for OLEDs: Donor-Acceptor Structure and NonDonor-Acceptor Structure. Adv. Mater. 2011, 23 (9), 1137-1144.

(4) Shurdha, E.; Repasy, B. K.; Miller, H. A.; Dees, K.; Iacono, S. T.; Ball, D. W.; Balaich, G. J. Symmetrical bis(fulvene) chromophores: model compounds for acceptor-donor-acceptor dye architectures. RSC Adv. 2014, 4 (79), 41989-41992.

(5) Lee, S. H.; Nakamura, T.; Tsutsui, T. Synthesis and Characterization of Oligo(9,9-dihexyl-2,7-fluorene ethynylene)s: For Application as Blue Light-Emitting Diode. Org. Lett. 2001, 3 (13), 2005-2007.

(6) Liu, C.; Li, Y.; Li, Y.; Yang, C.; Wu, H.; Qin, J.; Cao, Y. Efficient Solution-Processed Deep-Blue Organic Light-Emitting Diodes Based on Multibranched Oligofluorenes with a Phosphine Oxide Center. Chem. Mater. 2013, 25 (16), 3320-3327.

(7) Wu, H.-C.; Yu, A.-D.; Lee, W.-Y.; Liu, C.-L.; Chen, W.-C. A poly(fluorene-thiophene) donor with a tethered phenanthro[9,10d]imidazole acceptor for flexible nonvolatile flash resistive memory devices. Chem. Commun. 2012, 48 (73), 9135-9137.

(8) Thomas, K. R. J.; Kapoor, N.; Bolisetty, M. N. K. P.; Jou, J.-H.; Chen, Y.-L.; Jou, Y.-C. Pyrene-Fluorene Hybrids Containing Acetylene Linkage as Color-Tunable Emitting Materials for Organic Light-Emitting Diodes. J. Org. Chem. 2012, 77 (8), 3921-3932.

(9) Muenmart, D.; Tarsang, R.; Jungsuttiwong, S.; Keawin, T.; Sudyoadsuk, T.; Promarak, V. Synthesis and properties of fluoreneoligothiophenes perylenediimide triads and their electropolymerizations. J. Mater. Chem. 2012, 22 (29), 14579-14586.

(10) Duan, Z.; Hu, D.; Ohuchi, H.; Zhao, M.; Zhao, G.; Nishioka, Y. Organic field-effect transistors based on two phenylene-thiophene oligomer derivatives with a biphenyl or fluorene core. Synth. Met. 2012, 162 (13-14), 1292-1298.

(11) Slodek, A.; Zych, D.; Maroń, A.; Golba, S.; Schab-Balcerzak, E.; Janeczek, H.; Siwy, M.; Maćkowski, S. Fluorene vs carbazole substituent at quinoline core toward organic electronics. Dyes Pigm. 2019, 166, 98-106.

(12) Tang, S.; Liu, M.; Lu, P.; Cheng, G.; Zeng, M.; Xie, Z.; Xu, H.; Wang, H.; Yang, B.; Ma, Y.; Yan, D. Fluorene trimers with various 9,9'-substituents: The synthesis, characteristics, condensed state structures, and electroluminescence properties. Org. Electron. 2008, 9 (2), 241-252.

(13) Wang, X.; Hu, Y.-Z.; Chen, A.; Wu, Y.; Aggeler, R.; Low, Q.; Kang, H. C.; Gee, K. R. Water-soluble poly(2,7-dibenzosilole) as an ultra-bright fluorescent label for antibody-based flow cytometry. Chem. Commun. 2016, 52 (21), 4022-4024.

(14) Hibner-Kulicka, P.; Joule, J. A.; Skalik, J.; Bałczewski, P. Recent studies of the synthesis, functionalization, optoelectronic properties and applications of dibenzophospholes. RSC Adv. 2017, 7 (15), 9194-9236.

(15) Wu, B.; Yoshikai, N. Recent developments in synthetic methods for benzo[b]heteroles. Org. Biomol. Chem. 2016, 14 (24), $5402-5416$

(16) Parke, S. M.; Boone, M. P.; Rivard, E. Marriage of heavy main group elements with $\pi$-conjugated materials for optoelectronic applications. Chem. Commun. 2016, 52 (61), 9485-505.

(17) Green, J. P.; Wells, J. A. L.; Orthaber, A. Heavier pnictogens treasures for optical electronic and reactivity tuning. Dalton Trans. 2019, 48 (14), 4460-4466.

(18) Shameem, M. A.; Orthaber, A. Organophosphorus Compounds in Organic Electronics. Chem. - Eur. J. 2016, 22 (31), 10718-10735.

(19) Nakahama, T.; Kitagawa, D.; Sotome, H.; Ito, S.; Miyasaka, H.; Kobatake, S. Optical properties and solvatofluorochromism of fluorene derivatives bearing S,S-dioxidized thiophene. Photochem. Photobiol. Sci. 2016, 15 (10), 1254-1263.

(20) Mishra, A.; Ma, C.-Q.; Bäuerle, P. Functional Oligothiophenes: Molecular Design for Multidimensional Nanoarchitectures and Their Applications †. Chem. Rev. 2009, 109 (3), 1141-1276.

(21) Kim, D.; Reddy, M. R.; Cho, K.; Ho, D.; Kim, C.; Seo, S. Solution-processable fluorene derivative for organic thin-film transistors. Org. Electron. 2020, 76, 105464.

(22) Kamtekar, K. T.; Vaughan, H. L.; Lyons, B. P.; Monkman, A. P.; Pandya, S. U.; Bryce, M. R. Synthesis and Spectroscopy of Poly(9,9-dioctylfluorene-2,7-diyl-co-2,8-dihexyldibenzothiophene-S,Sdioxide-3,7-diyl)s: Solution-Processable, Deep-Blue Emitters with a High Triplet Energy. Macromolecules 2010, 43 (10), 4481-4488.

(23) Zuo, Z.; Ou, C.; Ding, Y.; Zhang, H.; Sun, S.; Xie, L.; Xia, R.; Huang, W. Spiro-substitution effect of terfluorenes on amplified spontaneous emission and lasing behaviors. J. Mater. Chem. C 2018, 6 (16), 4501-4507.

(24) Vidal, F.; Jakle, F. Functional Polymeric Materials Based on Main-Group Elements. Angew. Chem., Int. Ed. 2019, 58 (18), $5846-$ 5870.

(25) Deng, C.-L.; Bard, J. P.; Zakharov, L. N.; Johnson, D. W.; Haley, M. M. Naphtho[2,1-e]-1,2-azaphosphorine 2-Oxide Derivatives: Synthesis, Optoelectronic Properties, and Self-Dimerization Phenomena. J. Org. Chem. 2019, 84 (12), 8131-8139.

(26) Belyaev, A.; Cheng, Y.-H.; Liu, Z.-Y.; Karttunen, A. J.; Chou, P.T.; Koshevoy, I. O. A Facile Molecular Machine: Optically Triggered Counterion Migration by Charge Transfer of Linear Donor- $\pi$ Acceptor Phosphonium Fluorophores. Angew. Chem., Int. Ed. 2019, 58 (38), 13456-13465.

(27) Hirai, M.; Tanaka, N.; Sakai, M.; Yamaguchi, S. Structurally Constrained Boron-, Nitrogen-, Silicon-, and Phosphorus-Centered Polycyclic $\pi$-Conjugated Systems. Chem. Rev. 2019, 119 (14), 82918331.

(28) Baumgartner, T. Insights on the Design and Electron-Acceptor Properties of Conjugated Organophosphorus Materials. Acc. Chem. Res. 2014, 47 (5), 1613-1622.

(29) Morales Salazar, D.; Mijangos, E.; Pullen, S.; Gao, M.; Orthaber, A. Functional small-molecules \& polymers containing $\mathrm{P}=$ $\mathrm{C}$ and $\mathrm{As}=\mathrm{C}$ bonds as hybrid $\pi$-conjugated materials. Chem. Commun. 2017, 53 (6), 1120-1123.

(30) Svyaschenko, Y. V.; Orthaber, A.; Ott, S. Tuning the Electronic Properties of Acetylenic Fluorenes by Phosphaalkene Incorporation. Chem. - Eur. J. 2016, 22 (12), 4247-4255.

(31) Van der Knaap, T. A.; Bickelhaupt, F. (2,6-Dimethylphenyl)(9fluorenyliden)Phosphan. Chem. Ber. 1984, 117 (3), 915-924. 
(32) Typical procedures attempted to combine $\mathbf{1}$ and the thienyl boronic acid using $\mathrm{K}_{2} \mathrm{CO}_{3}$ (or $\mathrm{Cs}_{2} \mathrm{CO}_{3}$ ) and a solvent $(\mathrm{MeOH}$ or $\mathrm{MeOH} /$ water, THF, $\mathrm{MeOH}$ ) at room temperature or at elevated temperatures $\left(60^{\circ} \mathrm{C}\right)$.

(33) Lee, Y. H.; Morandi, B. Transition metal-mediated metathesis between $\mathrm{P}-\mathrm{C}$ and $\mathrm{M}-\mathrm{C}$ bonds: Beyond a side reaction. Coord. Chem. Rev. 2019, 386, 96-118.

(34) Kwong, F. Y.; Lai, C. W.; Tian, Y.; Chan, K. S. A novel synthesis of functionalised tertiary phosphines by palladium catalysed phosphination with triarylphosphines. Tetrahedron Lett. 2000, 41 (52), 10285-10289.

(35) Le Floch, P.; Carmichael, D.; Ricard, L.; Mathey, F. Palladium $(0)$-catalyzed functionalization of bromophosphinines. J. Am. Chem. Soc. 1993, 115 (23), 10665-10670.

(36) Fraysse, S.; Coudret, C. Unexpected formation of a scrambled aryl-phosphine oxide under modified sonogashira conditions. Tetrahedron Lett. 1999, 40 (52), 9249-9250.

(37) Van der Knaap, T. A.; Jenneskens, L. W.; Meeuwissen, H. J.; Bickelhaupt, F.; Walther, D.; Dinjus, E.; Uhlig, E.; Spek, A. L. Complex formation between nickel(0) and a phosphaalkene: influence of the second ligand on the $\eta^{1}$ - and $\eta^{2}$-coordination mode. J. Organomet. Chem. 1983, 254, C33-C36.

(38) Öberg, E.; Orthaber, A.; Lescop, C.; Réau, R.; Hissler, M.; Ott, S. Phosphorus Centers of Different Hybridization in PhosphaalkeneSubstituted Phospholes. Chem. - Eur. J. 2014, 20 (27), 8421-8432.

(39) Ito, S.; Zhai, L.; Mikami, K. Combination of $\mathrm{sp}^{2}$ - and $\mathrm{sp}^{3}$-Type Phosphorus Atoms for Gold Chemistry: Preparation, Structure, and Catalytic Activity of Gold Complexes That Bear Ligated 2-Silyl-1,3diphosphapropenes. Chem. - Asian J. 2011, 6 (11), 3077-3083.

(40) Miesel, D.; Korb, M.; Hildebrandt, A.; Lang, H. Synthesis and crystal structure of an acetylenic ferrocenyl substituted phosphaalkene. Inorg. Chim. Acta 2018, 471, 741-745.

(41) Rawe, B. W.; Brown, C. M.; MacKinnon, M. R.; Patrick, B. O.; Bodwell, G. J.; Gates, D. P. A C-Pyrenyl Poly(methylenephosphine): Oxidation "Turns On" Blue Photoluminescence in Solution and the Solid State. Organometallics 2017, 36 (14), 2520-2526.

(42) Nauroozi, D.; Orthaber, A. The Heavier Analogues of Alkenes: A Theoretical Comparison of Unsaturated Group 15/14 Systems. Eur. J. Inorg. Chem. 2016, 2016 (5), 709-717.

(43) The second disordered molecule shows very similar metrics and is not discussed herein.

(44) Seven phosphaalkene gold chloride complexes have been structurally characterized. mean $\mathrm{P}=\mathrm{C}, \mathrm{P}-\mathrm{Au}$ distances and $\mathrm{C}-\mathrm{P}=\mathrm{C}$ angles are $1.682 \AA$, $2.217 \AA$, and $110.7^{\circ}$.

(45) Orthaber, A.; Löfås, H.; Öberg, E.; Grigoriev, A.; Wallner, A.; Jafri, S. H. M.; Santoni, M.-P.; Ahuja, R.; Leifer, K.; Ottosson, H.; Ott, S. Cooperative Gold Nanoparticle Stabilization by Acetylenic Phosphaalkenes. Angew. Chem., Int. Ed. 2015, 54 (36), 10634-10638.

(46) Freytag, M.; Ito, S.; Yoshifuji, M. Coordination Behavior of Sterically Protected Phosphaalkenes on the $\mathrm{AuCl}$ Moiety Leading to Catalytic 1,6-Enyne Cycloisomerization. Chem. - Asian J. 2006, 1 (5), 693-700.

(47) Sheldrick, G. Crystal structure refinement with SHELXL. Acta Crystallogr., Sect. C: Struct. Chem. 2015, 71 (1), 3-8.

(48) Dolomanov, O. V.; Bourhis, L. J.; Gildea, R. J.; Howard, J. A. K.; Puschmann, H. OLEX2: a complete structure solution, refinement and analysis program. J. Appl. Crystallogr. 2009, 42 (2), 339-341.

(49) Bruno, I. J.; Cole, J. C.; Edgington, P. R.; Kessler, M.; Macrae, C. F.; McCabe, P.; Pearson, J.; Taylor, R. New software for searching the Cambridge Structural Database and visualizing crystal structures. Acta Crystallogr., Sect. B: Struct. Sci. 2002, 58 (3), 389-397.

(50) Frisch, M. J.; Trucks, G. W.; Schlegel, H. B.; Scuseria, G. E.; Robb, M. A.; Cheeseman, J. R.; Scalmani, G.; Barone, V.; Mennucci, B.; Petersson, G. A.; Nakatsuji, H.; Caricato, M.; Li, X.; Hratchian, H. P.; Izmaylov, A. F.; Bloino, J.; Zheng, G.; Sonnenberg, J. L.; Hada, M.; Ehara, M.; Toyota, K.; Fukuda, R.; Hasegawa, J.; Ishida, M.; Nakajima, T.; Honda, Y.; Kitao, O.; Nakai, H.; Vreven, T. J. A.; Montgomery, J.; Peralta, J. E.; Ogliaro, F.; Bearpark, M.; Heyd, J. J.; Brothers, E.; Kudin, K. N.; Staroverov, V. N.; Keith, T.; Kobayashi, R.;
Normand, J.; Raghavachari, K.; Rendell, A.; Burant, J. C.; Iyengar, S. S.; Tomasi, J.; Cossi, M.; Rega, N.; Millam, J. M.; Klene, M.; Knox, J. E.; Cross, J. B.; Bakken, V.; Adamo, C.; Jaramillo, J.; Gomperts, R.; Stratmann, R. E.; Yazyev, O.; Austin, A. J.; Cammi, R.; Pomelli, C.; Ochterski, J. W.; Martin, R. L.; Morokuma, K.; Zakrzewski, V. G.; Voth, G. A.; Salvador, P.; Dannenberg, J. J.; Dapprich, S.; Daniels, A. D.; Farkas, O.; Foresman, J. B.; Ortiz, J. V.; Cioslowski, J.; Fox, D. J. Gaussian 09, Revision D.01; Gaussian Inc.: Wallingford, CT, 2013.

(51) Compound 6 is isolated from the attempted synthesis of the disubstituted derivative as described in ref 29 . 